\title{
Basin Structure beneath the Santa Rosa Plain, Northern California: Implications for Damage Caused by the 1969 Santa Rosa and 1906 San Francisco Earthquakes
}

\author{
by D. K. McPhee, V. E. Langenheim, S. Hartzell, R. J. McLaughlin, B. T. Aagaard, \\ R. C. Jachens, and C. McCabe
}

\begin{abstract}
Regional gravity data in the northern San Francisco Bay region reflect a complex basin configuration beneath the Santa Rosa plain that likely contributed to the significant damage to the city of Santa Rosa caused by the 1969 M 5.6, 5.7 Santa Rosa earthquakes and the 1906 M 7.9 San Francisco earthquake. Inversion of these data indicates that the Santa Rosa plain is underlain by two sedimentary basins about $2 \mathrm{~km}$ deep separated by the Trenton Ridge, a shallow west-northwest-striking bedrock ridge west of Santa Rosa. The city of Santa Rosa is situated above the 2$\mathrm{km}$-wide protruding northeast corner of the southern basin where damage from both the 1969 and 1906 earthquakes was concentrated. Ground-motion simulations of the 1969 and 1906 earthquakes, two events with opposing azimuths, using the gravitydefined basin surface, show enhanced ground motions along the northeastern edge of this corner, suggesting that basin-edge effects contributed to the concentration of shaking damage in this area in the past and may also contribute to strong shaking during future earthquakes.
\end{abstract}

\section{Introduction}

The $M 7.91906$ San Francisco earthquake severely damaged much of the city of San Francisco, but also inflicted catastrophic destruction on the city of Santa Rosa (Fig. 1), located $\sim 40 \mathrm{~km}$ east of the San Andreas fault rupture in the heart of wine country in the northern San Francisco Bay region. The shaking and resultant fire in Santa Rosa caused 61 deaths, with at least a dozen missing, and practically razed the business district of the city (Lawson, 1908). The equivalent of seven to eight blocks were destroyed by the earthquake and about four to five additional blocks were destroyed by the fire in downtown Santa Rosa (Lawson, 1908). Santa Rosa was regarded by Lawson (1908) as one of the locations that experienced the strongest shaking in the 1906 earthquake, which is surprising considering its distance from the rupture, and a recent re-examination and compilation of 1906 intensity data (Boatwright and Bundock, 2005; Boatwright and Bundock, in press) confirm that Santa Rosa was heavily affected by ground shaking.

Santa Rosa was again severely shaken in October 1969, when magnitude $\left(M_{\mathrm{L}}\right) 5.6$ and 5.7 earthquakes occurred within 2 hours of each other near the city (Wong and Bott, 1995) (Fig. 2). The locations and focal mechanisms of these events indicate right-lateral strike-slip faulting at the southern end of the northwest-striking Healdsburg fault (Wong and Bott, 1995). These are the only two earthquakes to strongly affect the northern San Francisco Bay region since the 1906 San Francisco earthquake, and they caused millions of dollars of structural damage within a relatively concentrated area of the city of Santa Rosa, including buckled curbs and sidewalks, broken waterlines, and damage to several modern earthquake-resistant buildings (Fig. 3) (Cloud et al., 1970; Steinbrugge, 1970). More surprisingly, the severity of the damage in this area was considerably greater than would be expected for a moderate-magnitude earthquake (Steinbrugge, 1970) and coincided spatially with severe damage caused by the 1906 earthquake.

Youd and Hoose (1978) suggested that 1969 earthquake damage in Santa Rosa was purely a consequence of ground shaking rather than ground failure due to the lack of landslides, lateral spreads, ground cracks, and liquefaction in the area. Cloud et al. (1970) suggested that a combination of factors was responsible for the concentration and distribution of damage from the 1969 earthquakes: (1) the proximity of the mainshocks; (2) ground-motion amplification due to the presence of soft alluvial materials directly beneath the city; and (3) the characteristics of nearby geologic formations. Steinbrugge (1970) attributed the concentrated damage in the city of Santa Rosa to the distribution of buried watersaturated stream channels, poorly consolidated alluvium, and artificial fill. Although such deposits are present in the 

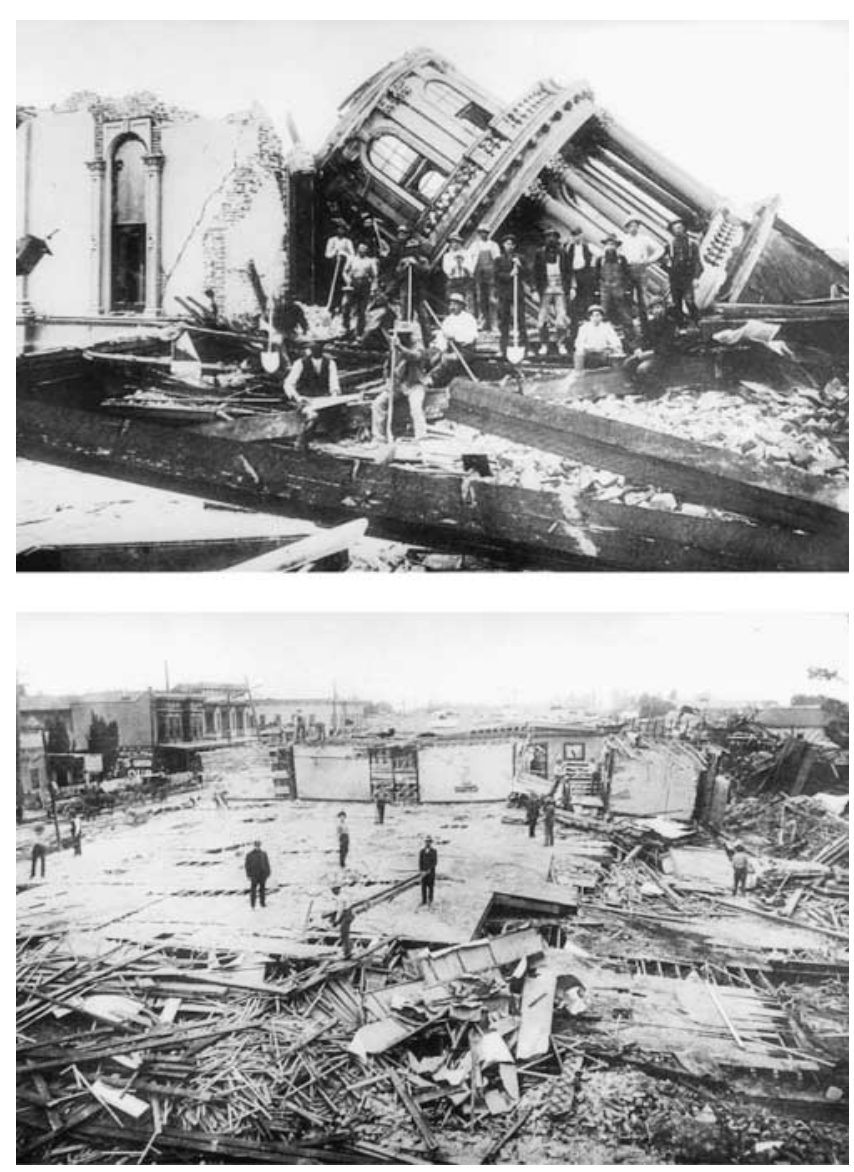

Figure 1. Photos showing damage in downtown Santa Rosa after the 1906 earthquake (from the Karl V. Steinbrugge Collection, Earthquake Engineering Research Center, University of California, Berkeley).

damaged area, they are also present beneath much of the Santa Rosa plain and in various valleys east of the Rodgers Creek-Healdsburg faults, yet damage was not ubiquitous in these areas. Noting this, Steinbrugge (1970) also suggested that basin-edge effects caused shaking amplification that contributed to the damage.

Numerous studies during the past century have demonstrated that sedimentary basins can both amplify and prolong ground shaking from earthquakes (e.g., Reid, 1910; Gutenberg, 1957; Aki and Larner, 1970; Trifunac, 1971). Often, the distribution of this amplification and consequent shaking damage is spatially complex and not simply a function of basin depth. The location of fault rupture relative to the basin and the direction of rupture propagation affect the distribution of shaking along the edges and within the basin. As a result, it is only in about the past decade with the development of 3D models of basin structures and modern computational resources that studies have been able to focus on the correlation between 3D basin geometry and observed shaking in earthquakes (e.g., Frankel and Vidale, 1992; Olsen and Archuleta, 1996; Wald and Graves, 1998; Graves et al., 1998; Pitarka et al., 1998).
Inverting gravity data using geologic constraints unveils a basin configuration beneath the Santa Rosa plain that may indeed have played a role in causing the local distribution of shaking damage. Our identification of a protruding basin corner that extends directly beneath the city of Santa Rosa correlates well with the distribution of damage observed in the 1969 and 1906 earthquakes. In addition, simulation of one of the 1969 events as well as the 1906 earthquake using the basin configuration shows enhanced ground motion in the area of moderate to severe earthquake-related damage at the margin of this basin.

\section{Gravity Data and Basin Geometry}

Regional gravity data (Fig. 4a) reflect density contrasts within the upper and middle crust from which we can infer the 3D geometry of young Cenozoic basins and structures. One of the most prominent density contrasts in the California Coast Ranges is that between relatively dense Mesozoic basement rocks and less dense Cenozoic sedimentary and volcanic rocks. Basement rocks exposed in the hills around the Santa Rosa plain include rocks of the Franciscan Complex, Coast Range ophiolite, and Great Valley sequence (Fig. 2) (McLaughlin et al., 2005). Sedimentary rocks in the Santa Rosa plain, based on a few deep oil and gas drill holes in the southern part of the plain, comprise as much as $130 \mathrm{~m}$ of Quaternary and Late Pliocene alluvial fan and basin deposits underlain by $\sim 500 \mathrm{~m}$ of early to late Pliocene fluvial and estuarine to marine littoral and shelf sediments and $\sim 1 \mathrm{~km}$ of Miocene fluvial to estuarine sedimentary rocks that are intercalated with volcanics that are $\sim 6$ to $10 \mathrm{Ma}$. Typical densities and compressional wave velocities of these sedimentary rocks can be found in Brocher (2005b).

Gravity highs occur over outcrops of basement rocks, areas of thin sedimentary cover, and dense volcanic rocks; gravity lows correspond with areas of thick, low-density sedimentary fill. In this study, regional gravity data (Chapman and Bishop, 1974; Chapman et al., 1983) were augmented by about 300 new stations with an average density of one station per square kilometer (Langenheim et al., 2006).

The Santa Rosa plain at the approximate latitude of Santa Rosa is characterized by a pronounced west-northwest-trending gravity high that separates two large gravity lows caused by thick, low-density Cenozoic deposits (Fig. 4a). The northern gravity low is centered near the town of Windsor (Fig. 2). The southern gravity low, here called the Cotati low, has the lowest gravity values in the Santa Rosa plain, reflecting the thickest part of the basin fill located 3-4 km south of the west-northwest-trending gravity high. Santa Rosa is located on the northeastern corner of the Cotati gravity low (Fig. 4a).

To examine the basement structure beneath the Santa Rosa plain, we invert these gravity data to produce a basin thickness map (Fig. 4b). The inversion method is iterative and requires an initial basin gravity field, areal geology to define areas of exposed basement, a vertical density curve 


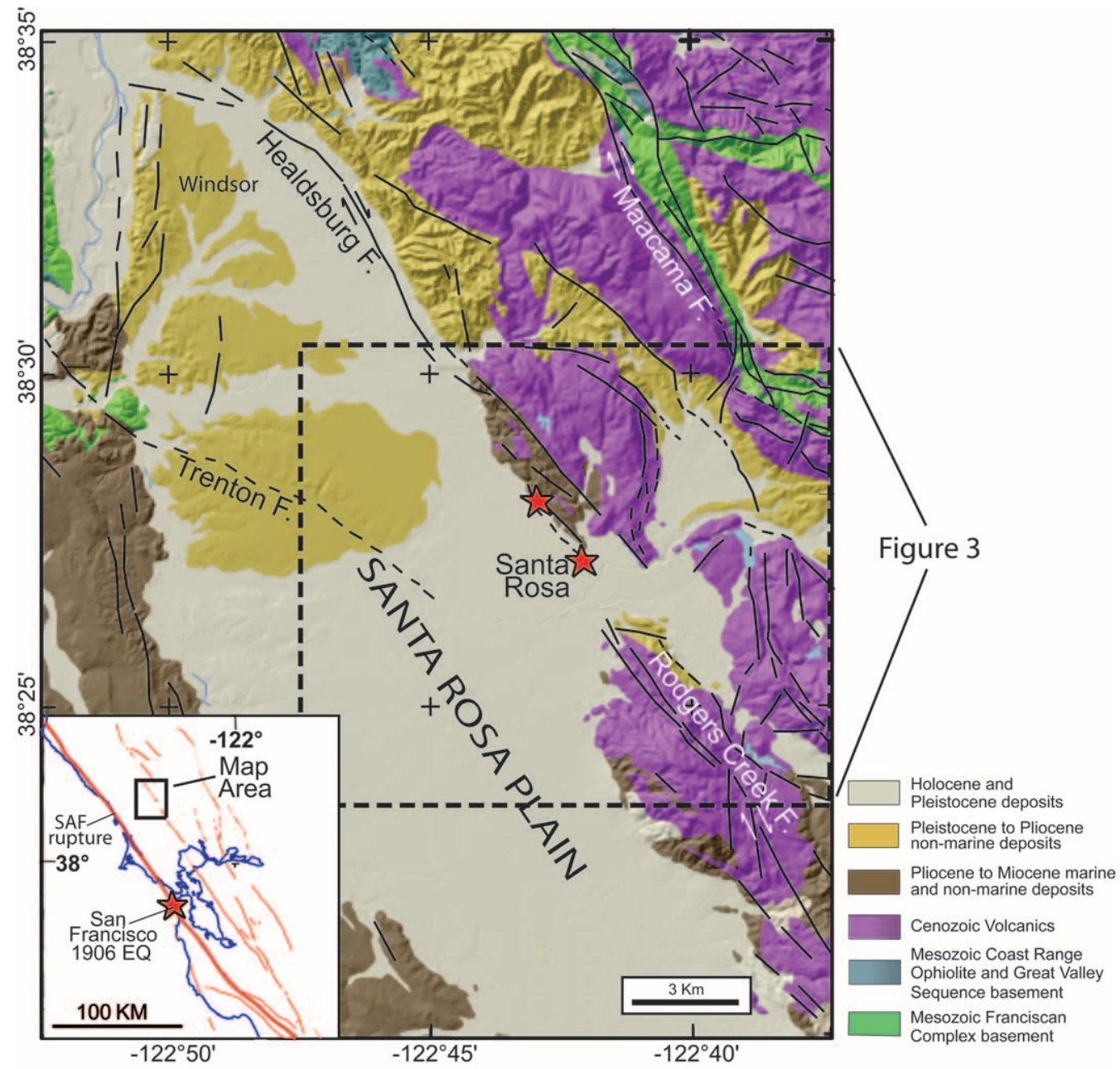

Figure 2. Simplified geologic map of the Santa Rosa plain and major faults that bound the plain (modified from McLaughlin et al., 2005). The epicenters of the 1969 Santa Rosa earthquake sequence (Wong and Bott, 1995) and the 1906 earthquake (Lomax, 2005; inset) are marked by red stars.

for the Cenozoic basin deposits (Jachens and Moring, 1990), and a density value for basement rock. Depth to basement in wells deep enough to intersect basement adds a further constraint (Fig. 4b). The basin gravity field is obtained from the subtraction of a regional gravity field based on gravity measurements made only on basement outcrops from the isostatic gravity field. The regional gravity field is then modified at each iteration. The density-depth function used here (Table 1) is based on the density log of a 3-km-deep drill hole in San Pablo Bay, the nearest basin for which such data are available (Smith, 1992). The method assumes no lateral density variations within the basin fill. This method is a useful tool for predicting the shapes of basins, but it can be less effective in estimating the actual magnitude of basin thicknesses because of uncertainties in the local density-depth relation and the assumption of one-dimensional variations (Phelps et al., 1999).

The gravity inversion (Fig. 4b) delineates two prominent basins beneath the Santa Rosa plain, the Windsor basin to the north and the Cotati basin to the south. These basins have maximum thicknesses of approximately $1.5 \mathrm{~km}$ and $2 \mathrm{~km}$, respectively, and are separated by a shallow $(\sim 200 \mathrm{~m}$ deep) west-northwest-striking basement ridge which we call the Trenton ridge. The Trenton ridge coincides approximately with the location at the surface of the northweststriking, northeast-dipping Trenton thrust fault, although the basement ridge itself appears to be bisected by the fault.

Major damage from shaking in the 1969 and 1906 earthquakes was concentrated southwest of a probable small releasing bend or right-stepped connection between the Rodgers Creek and Healdsburg faults that is obscured at the surface by Quaternary deposits (Fig. 2 and 4). Damage was nestled between the eastern end of the Trenton ridge and the basement high marking the eastern margin of the Cotati basin (Fig. 4b). The extensive damage in the 1969 and 1906 earthquakes in Santa Rosa was coincident with a 2-km-wide gravity low associated with a basement depression $\sim 1 \mathrm{~km}$ deep in the northeast corner of the Cotati basin and, in particular, the most concentrated damage occurred at the northeastern margin of this depression (Fig. 4). 


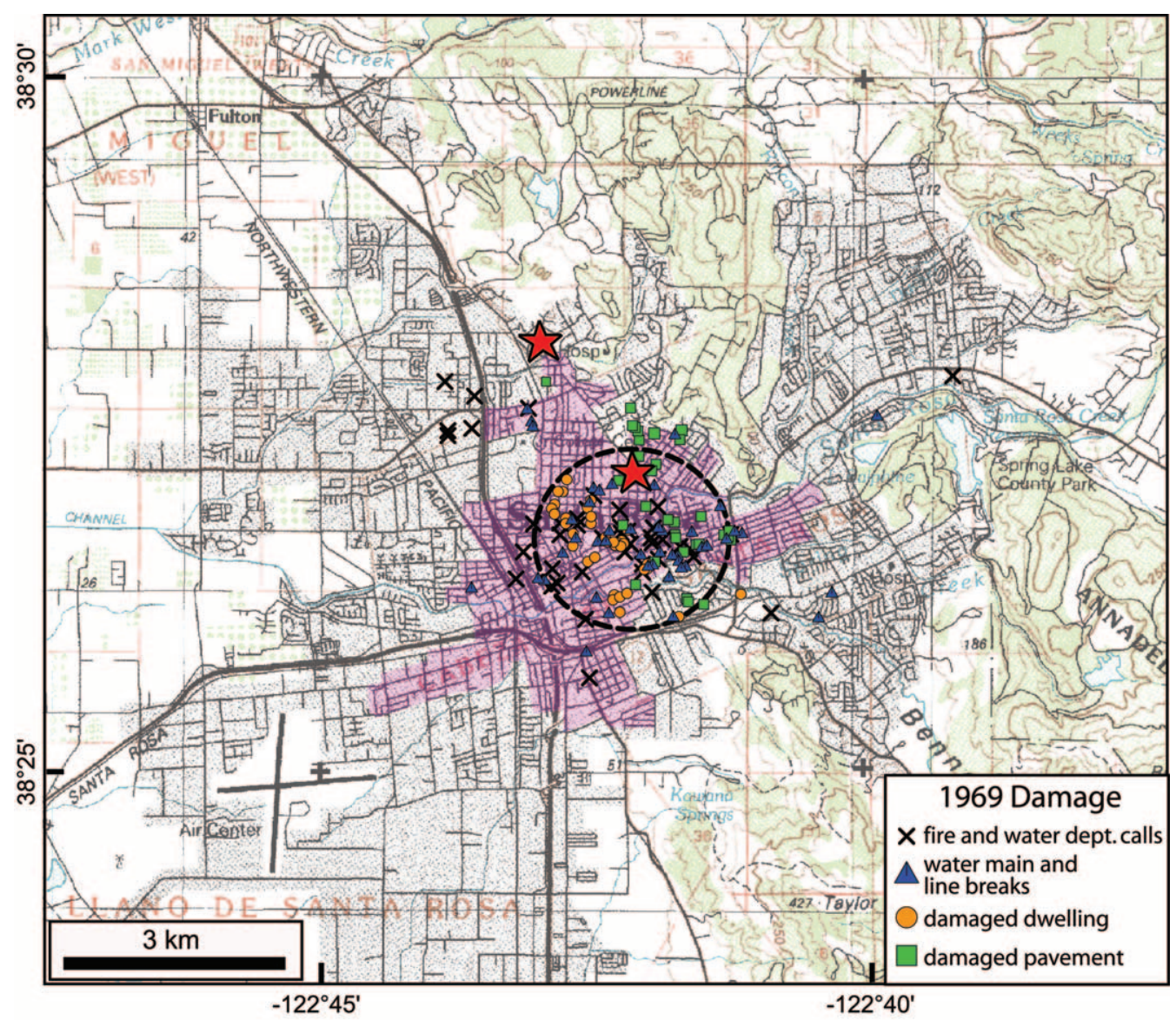

Figure 3. Section taken from the 1:100,000 Santa Rosa, California, quadrangle map (photorevised 1980). The area in pink shows the city limits taken from the 1954 Santa Rosa, California, 1:62,500 quadrangle map. Note that by 1969 the city was larger. Dashed circle is drawn around the majority of the 1969 earthquake damage (Steinbrugge, 1970) and will be used for reference in later figures. Santa Rosa earthquake epicenters shown by red stars.

\section{Ground-Motion Simulations}

\section{Earthquakes}

As a test of our hypothesis that the basin geometry beneath Santa Rosa played a role in causing the local distribution of shaking damage, we simulate the expected ground motion from the first M 5.6 event on 1 October 1969 (0456 GMT, 2 October) using USGS Bay Area Velocity Model 05.1.0, an updated version of the 3D velocity model (Brocher, 2005a) calculated from the gravity-derived basement surface. Synthetic waveforms are calculated using the $3 \mathrm{D}$ velocity-stress, staggered-grid, finite-difference code developed by Liu and Archuleta (2002). The code models the full wave field in a solid viscoelastic, heterogeneous, isotropic Earth with fourth-order accuracy in space and secondorder accuracy in time. This code has been used extensively to model basin-related ground-motion effects in the Santa Clara Valley, south of the San Francisco Bay (Hartzell et al., 2006). Anelastic attenuation is included in the simulation by a realistic frequency-independent $Q$ utilizing the memory variables method of Day and Bradley (2001), with modifications by Liu and Archuleta (2006). Waveforms are calculated to an upper frequency limit of $1.0 \mathrm{~Hz}$ for a minimum surface shear-wave velocity of $300 \mathrm{~m} / \mathrm{sec}$. The source, based on the hypocentral location of the earthquake with a depth of $6.2 \mathrm{~km}$ (Wong and Bott, 1995), has a strike of $135^{\circ}$ clockwise from north, consistent with the orientation of the Rodgers Creek-Healdsburg fault zone, with a dip and rake of $90^{\circ}$ and $180^{\circ}$, respectively. Because of the relatively small magnitude of this event, the earthquake is approximated by a single point source.

The pattern of peak velocities (Fig. 5a) shows that the deepest parts of the Cotati and Windsor Basins are areas of enhanced ground motion, caused by the amplification of seismic waves by lower-velocity basin sediments and the trapping of seismic energy within the basins. In addition, there is an area of locally elevated ground motion near Santa Rosa on the edge of the Cotati Basin. This high correlates well with a local depression in the Quaternary/Tertiary contact at a depth of about $200 \mathrm{~m}$. Therefore, the highs over the 
(a)

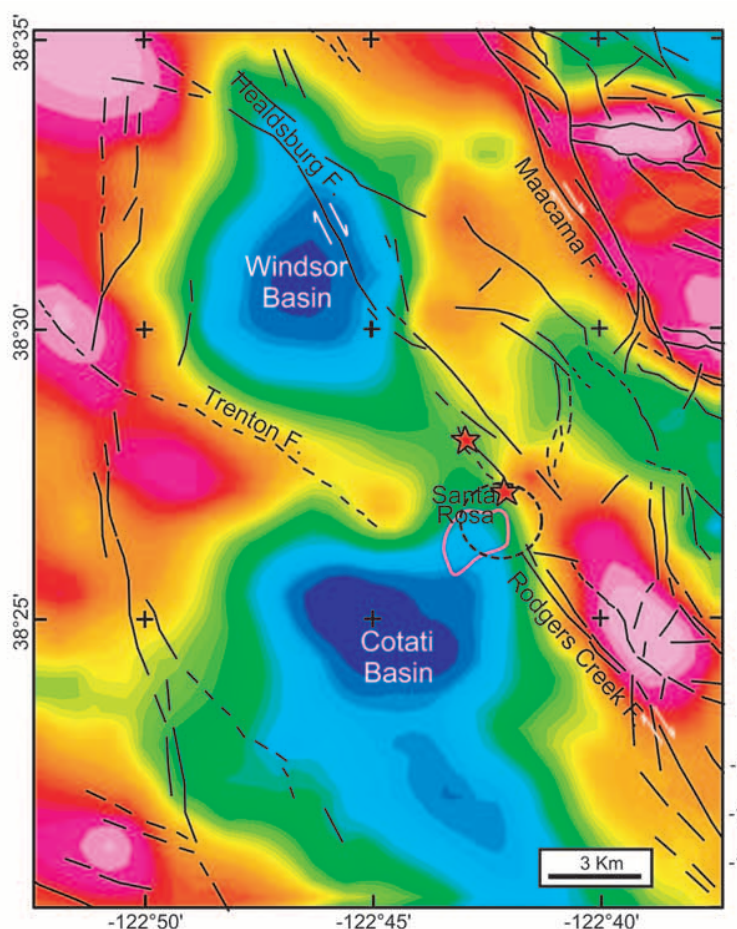

(b)

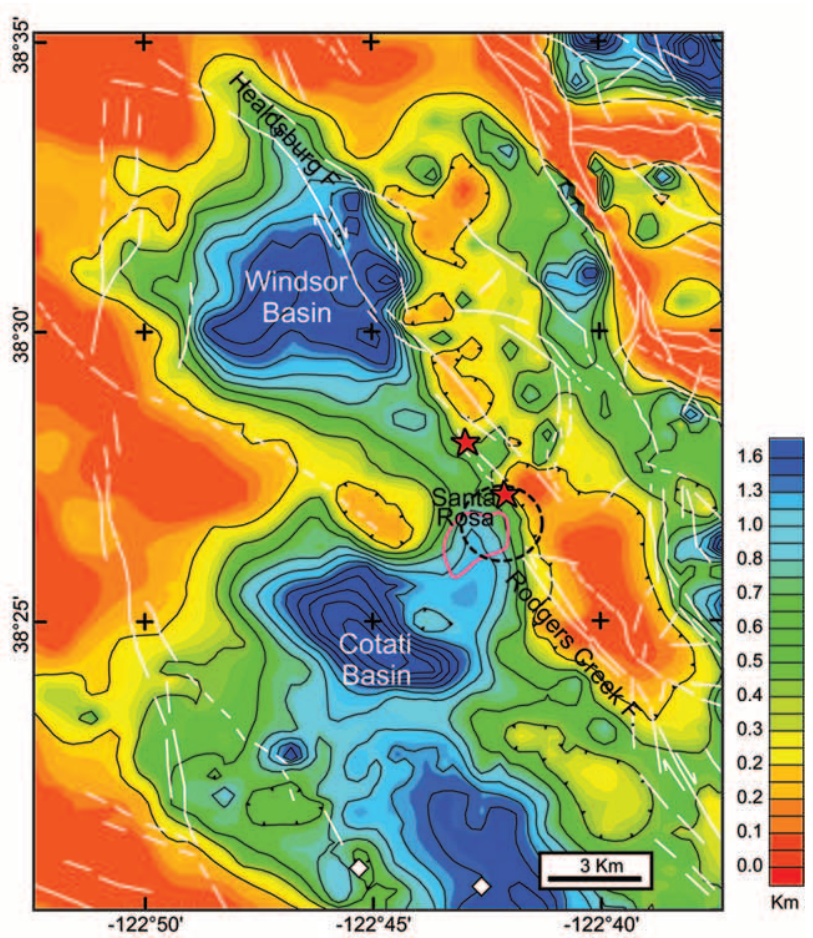

Figure 4. (a) Isostatic gravity map of the Santa Rosa plain. Damage circle (Fig. 3) and epicenters of the 1969 earthquakes are also shown. Area of moderate and severe damage caused by the 1906 earthquake (Lawson, 1908) shown by pink closed curve. (b) Basin thickness map as defined by inversion of gravity data. Contour interval $0.2 \mathrm{~km}$. White diamonds show locations of basement wells used to constrain the in version. Basement depths at these wells, from west to east, are $975 \mathrm{~m}$ and $1682 \mathrm{~m}$.

Table 1

Density-Depth Function

\begin{tabular}{cc}
\hline $\begin{array}{c}\text { Depth Range } \\
(\mathrm{m})\end{array}$ & $\begin{array}{c}\text { Density Contrast* } \\
\left(\mathrm{g} / \mathrm{cm}^{3}\right)\end{array}$ \\
\hline $0-300$ & -0.48 \\
$300-1300$ & -0.32 \\
$1300-2300$ & -0.27 \\
$2300-3300$ & -0.17 \\
$>3300$ & -0.10 \\
\hline
\end{tabular}

*Density contrast of Cenozoic sedimentary and volcanic rocks relative to underlying pre-Cenozoic bedrock $\left(2.67 \mathrm{~g} / \mathrm{cm}^{3}\right)$ composed of Franciscan Complex and Great Valley Sequence.

Cotati/Windsor Basins and near Santa Rosa can be attributed to deep and shallow basin effects, respectively. There is also an interesting lineation of high peak velocity over the Trenton Ridge, coinciding with the northwest-trending Trenton fault. We speculate that this high is due to the lower attenuation of $1-\mathrm{Hz}$ energy through the higher-velocity, lowerattenuating Trenton Ridge compared with that of ray paths through the low-velocity sediments of the Cotati Basin. A similar high in ground motion was observed in the Santa Clara Valley at frequencies above $1 \mathrm{~Hz}$ over the central- valley ridge separating the Cupertino and Evergreen Basins (Hartzell et al., 2006).

A reference simulation for the ground motion was computed using an identical earthquake source with a velocity model devoid of basement structure (Fig. 5b). In this case, the velocity varied uniformly with depth over the entire model space. The minimum $P$ - and $S$-wave velocities, 1200 and $300 \mathrm{~m} / \mathrm{sec}$, respectively, were the same in both models. The results show the expected four-lobed radiation pattern for $S H$ waves. The northern two lobes are smaller in spatial extent because they are cut off by the edge of the velocity grid, which has an absorbing boundary. The maximum peak velocity in the reference simulation is approximately half of that calculated for the model containing basin structure (Fig. 5a). Based on this reference, the basins appear to amplify the seismic waves by roughly a factor of 2 to 3 , playing a significant role in shaping the local ground-motion distribution.

Ground motion over the Cotati Basin is not only larger in amplitude than nonbasin sites, but also significantly longer in duration (Fig. 6). The long-duration ground motion is characteristic of surface-wave energy trapped within the basin. The sites near Santa Rosa also show larger amplitudes (Fig. 6), but the durations are not as long as the Cotati Basin, perhaps reflecting the shallower origin of the amplification. 
(a)

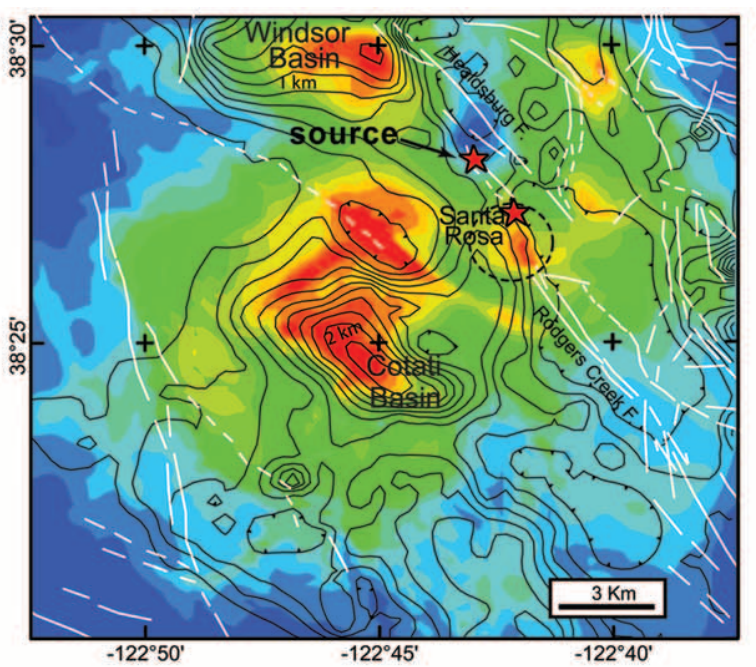

(b)

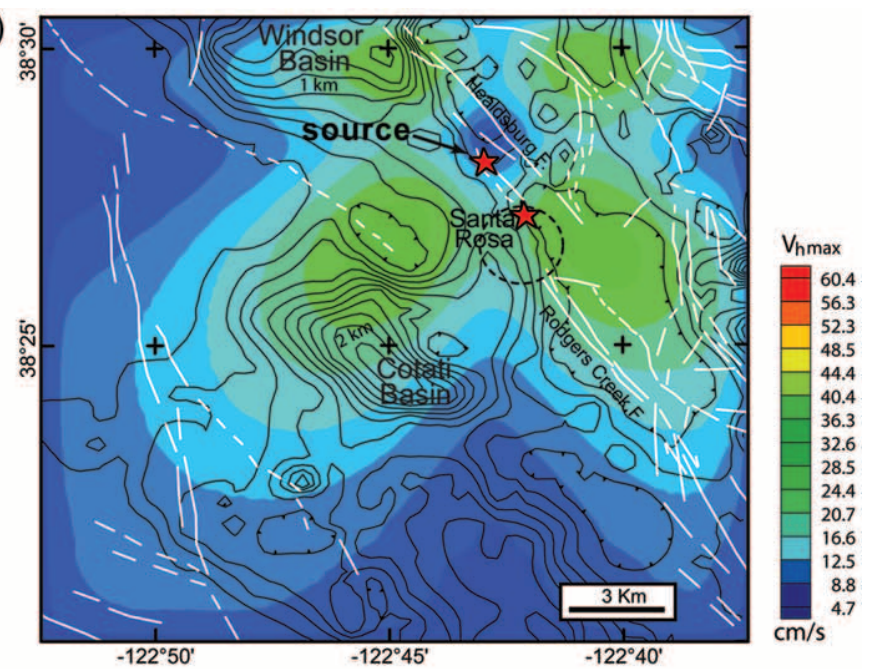

Figure 5. (a) The maximum horizontal velocity in the study area calculated from the vector of horizontal motion, $\max _{t} \sqrt{ }\left(V_{x}^{2}(t)+V_{y}^{2}(t)\right)$, with 0.2 -km basement contours from Figure $4 \mathrm{~b}$. The source is located at a depth of $6.2 \mathrm{~km}$ below the northernmost Santa Rosa earthquake epicenter (red star). Damage circle from Figure 3 also shown.

Note area of map is smaller than in Figure 4. (b) Result of identical simulation as in (a) but without the basement structure incorporated into the model. Note the maximum velocity is approximately half of that calculated for the model in (a).
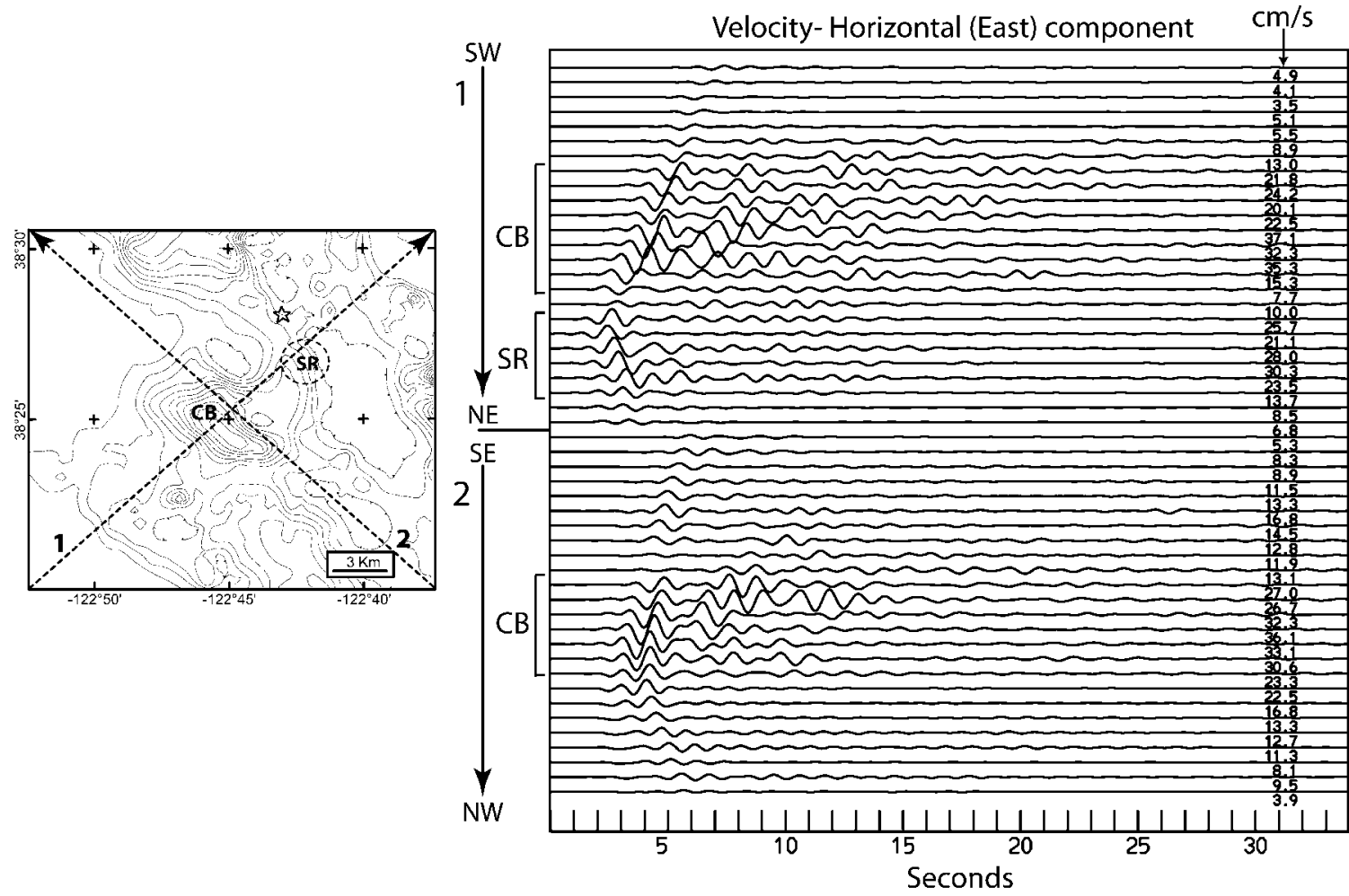

Figure 6. Selected velocity time histories (east component) from the study area shown in Figure 5. Maximum velocities along each $\sim 30$-sec segment are labeled on the right. Paths along which the velocities are shown (1 and 2) are drawn on the map at the left with $0.2 \mathrm{~km}$ basement contours for reference. CB refers to approximate location of ground motion high observed over the Cotati Basin; SR refers to high observed near Santa Rosa (see Fig. 5a). 


\section{Earthquake}

We now examine the ground shaking in the Santa Rosa area for the 1906 M 7.9 earthquake using the ground motions from Aagaard's SF1906Song2c simulation (Aagaard et al., unpublished work). Aagaard et al. (unpublished work) discusses the details of the modeling and the ground motions from a regional perspective; in this study we focus on the relationship between the spatial distribution of the peak velocities and the geometry of the basins underneath the Santa Rosa plain. Although only the large-scale features of the source are constrained (Song et al., in press), we can test whether the Cotati and Windsor basins explain the concentrated region of damage in Santa Rosa. The simulations use a finite-element code (Aagaard et al., 2001) where the motions are calculated for an upper frequency limit of $0.5 \mathrm{~Hz}$ and a minimum shear-wave speed of $700 \mathrm{~m} / \mathrm{sec}$. Topography is included but anelastic attenuation is not.

The energy arriving in the Santa Rosa area is dominated by Love and Rayleigh waves radiated as the rupture propagates northward along the San Andreas fault through the Point Reyes area, 30-60 km north of the epicenter. As these surface waves enter the Cotati and Windsor basins, they are immediately amplified (by a factor of 2 or more) as a result of the more compliant basin deposits relative to the surrounding basement. This results in a strong correlation between the peak velocities and the depth to basement (Fig. 7). The basin depth appears to have the greatest influence, but basin edge effects also play a significant role. The basin edges contribute to the distribution of shaking as the sharp contrast in rigidity at the edges of the basins reflect energy back into the basins from seismic waves attempting to propagate from the basins into the surrounding basement. This sets up complex interactions between later arriving Love waves originating from rupture west of Santa Rosa (north of the Point Reyes area) and the waves bouncing around the basins, and leads to the large peak velocities in Santa Rosa at the northeast corner of the Cotati basin. The groundmotion simulations of the 1906 earthquake demonstrate that the local sedimentary basin structure likely played a major role in shaping the distribution of damaging ground motion in 1906, but the transonic rupture speed (rupture propagation between the $S$ - and $P$-wave speeds) and region of large slip north of San Francisco may have also contributed (Boatwright and Bundock, in press; Aagaard et al., unpublished work).

\section{Discussion and Conclusions}

Gravity data show that the Santa Rosa plain is underlain by two prominent basins separated by a shallow west-northwest-striking bedrock ridge. The most extensive damage in Santa Rosa from the 1969 earthquakes coincides with the edge of a gravity low that reflects a basement depression in the northeast corner of the Cotati basin. A simulation of the first M 5.6 event on 1 October 1969 shows elevated ground

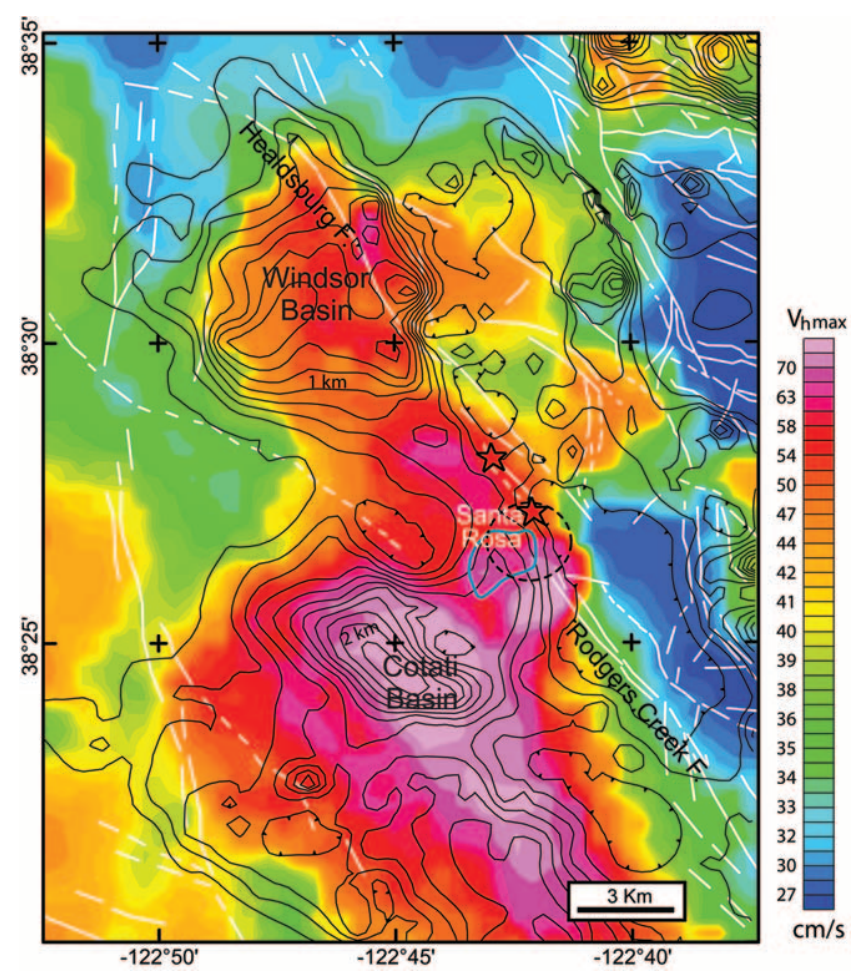

Figure 7. The maximum magnitude of the horizontal ground-velocity vector from the simulation of the 1906 earthquake with $0.2 \mathrm{~km}$ basement contours from Figure $4 \mathrm{~b}$. The blue closed curve outlines the area of moderate and severe damage caused by the 1906 earthquake (Lawson, 1908).

motions along the northeastern edge of this corner depression suggesting that basin-edge effects contributed to the concentration of shaking damage in this area. Similar behavior is observed in ground-motion simulations of the M 7.91906 earthquake on the San Andreas fault to the west and from the opposite azimuth, even though the 1906 rupture was much farther from Santa Rosa. The areas in our simulations characterized by the enhanced ground motions in the central Windsor and Cotati basins suggest that these areas also likely experienced strong shaking, but they were only sparsely populated in 1969 and even less so in 1906; thus, little damage was experienced in these regions.

The ground-motion simulations in this study do not include shallow near-surface sediments at length scales of tens of meters. Such localized variations in shallow ground conditions may have also influenced the distribution of shaking and damage. To differentiate the seismic-wave amplification effects of such near-surface geology from deeper basin effects, the determination of site-response characteristics in the region is necessary. Current studies estimating site response in the northern San Francisco Bay area show high site response at stations located at the edge of basins in the Santa Rosa plain (Lin et al., 2006; K. J. Bergen, personal comm.). Preliminary results suggest that near-surface geology may explain the strong response calculated at one site near Santa 
Rosa (K. J. Bergen, personal comm.). Further analysis of these site-response characteristics with respect to basin geometry in the Santa Rosa plain will help quantify the effects of near-surface geology on shaking in the area.

Santa Rosa was severely damaged by both the great 1906 San Francisco earthquake and the 1969 earthquake sequence on the nearby Healdsburg fault, the only large earthquakes to significantly impact the northern San Francisco Bay area during the past century. Ground-motion simulations of these earthquakes indicate that Santa Rosa's location relative to the Cotati basin likely played a significant role in controlling the distribution of damage caused by both of these seismic events, even though the hypocenters were in very different locations relative to Santa Rosa. Without examining in detail many other local and regional sources of earthquake ruptures, we do not know how the basins influence the distribution of shaking for all azimuths and rupture geometries. Nevertheless, observations from and modeling of the 1906 and 1969 earthquakes suggest that locations above the deepest portions of the basins as well as those above steep edges, such as Santa Rosa, appear susceptible to particularly strong shaking in a wide variety of cases. Characterizing low-velocity basins and their detailed shapes are clearly an essential component for characterizing the seismic hazard.

\section{Acknowledgments}

We are grateful to Bob Simpson for his help with preparing the velocity/density grid used in the 1969 simulation. Carter Roberts helped with the gravity data collection. Jack Boatwright provided valuable input and reviewed an earlier version of this article. Reviews by Tom Brocher and Carl Wentworth helped clarify and improve the manuscript. We also thank Greg Beroza, Chris Wills and an anonymous reviewer for their valuable suggestions.

\section{References}

Aagaard, B. T., J. F. Hall, and T. H. Heaton (2001). Characterization of near-source ground motions with earthquake simulations, Earthquake Spectra 17, 177-207.

Aki, K., and K. L. Larner (1970). Surface motion of a layered medium having an irregular interface due to incident plane SH wave, J. Geophys. Res. 75, 933-954.

Boatwright, J., and H. Bundock (2005). Modified Mercalli intensity maps for the 1906 San Francisco earthquake plotted in ShakeMap format, U.S. Geol. Surv. Open-File Rept. 2005-1135, http://pubs.usgs.gov/of/ 2005/1135/ (last accessed February 2007).

Boatwright, J., and H. Bundock (????). The distribution of Modified Mercalli Intensity in the April 18, 1906, San Francisco, earthquake, Bull. Seism. Soc. Am. (in press).

Brocher, T. M. (2005a). Compressional and shear wave velocity versus depth in the San Francisco Bay area, California: Rules for USGS Bay area velocity model 05.0.0, U.S. Geol. Surv. Open-File Rept. 2005$1317,58 \mathrm{pp}$.

Brocher, T. M. (2005b). A regional view of urban sedimentary basins in Northern California based on oil industry compressional-wave velocity and density logs, Bull. Seism. Soc. Am. 95, 2093-2114.

Chapman, R. H., and C. C. Bishop (1974). Bouguer gravity map of Cali- fornia, Santa Rosa Sheet, California Division of Mines and Geology Map, scale 1:250,000.

Chapman, R. H., G. W. Chase, and L. G. Youngs (1983). Geophysical study of the Santa Rosa geothermal area, Sonoma County, California, California Division of Mines and Geology Open-File Report 83-9.

Cloud, W. K., D. M. Hill, M. E. Huffman, C. W. Jennings, T. V. McEvilly, R. D. Nason, K. V. Steinbrugge, D. Tocher, J. D. Unger, and T. L. Youd (1970). The Santa Rosa earthquakes of October, 1969, Calif. Div. Mines Geol. 23, 43-63.

Day, S. M., and C. R. Bradley (2001). Memory-efficient simulation of anelastic wave propagation, Bull. Seism. Soc. Am. 95, 520-531.

Frankel, A., and J. Vidale (1992). A three-dimensional simulation of seismic waves in the Santa Clara Valley, California, from a Loma Prieta aftershock, Bull. Seism. Soc. Am. 82, 2045-2074.

Graves, R. W., A. Pitarka, and P. G. Somerville (1998). Ground motion amplification in the Santa Monica area: effects of shallow basin edge structure, Bull. Seism. Soc. Am. 88, 1224-1242.

Gutenberg, B. (1957). Effects of ground on earthquake motion, Bull. Seism. Soc. Am. 47, 221-250.

Hartzell, S., S. Harmsen, R. A. Williams, D. Carver, A. Frankel, G. Choy, P-C. Liu, R. C. Jachens, T. M. Brocher, and C. M. Wentworth (2006). Modeling and validation of a 3D velocity structure for the Santa Clara Valley, California, for seismic wave simulations, Bull. Seism. Soc. Am. 96, 1851-1881.

Jachens, R. C., and B. C. Moring (1990). Maps of the thickness of Cenozoic deposits and the isostatic residual gravity over basement for Nevada, U.S. Geol. Surv. Open-File Rept. 90-404, 15 pp., 2 plates.

Langenheim, V. E., C. W. Roberts, C. A. McCabe, D. K. McPhee, J. E. Tilden, and R. C. Jachens (2006). Preliminary isostatic gravity map of the Sonoma Volcanic Field and vicinity, Sonoma and Napa Counties, California, U.S. Geol. Surv. Open-File Rept. 2006-1056, http:// pubs.usgs.gov/of/2006/1056/ (last accessed July 2006).

Lawson, A. C. (1908). The California earthquake of April 18, 1906, Carnegie Inst. Washington Publ. 87, 1451 p.

Lin, H., Y. Chen, R. Sell, W. Mooney, S. Detweiler, J. Fletcher, and J. Boatwright (2006). Earth structure and site response in the northern San Francisco Bay area (abstract). Seismologic Society of America Annual Meeting, San Francisco, California, 18-22 April 2006.

Liu, P-C, and R. J. Archuleta (2002). The effect of a low-velocity surface layer on simulated ground motion, Seism. Res. Lett. 73, 267.

Liu, P-C, and R. J. Archuleta (2006). Efficiency modeling of Q for 3D numerical simulation of wave propagation, Bull. Seism. Soc. Am. 96, 1352-1358.

Lomax, A. (2005). A reanalysis of the hypocentral location and related observations for the great 1906 California earthquake, Bull. Seism. Soc. Am. 95, 861-877.

McLaughlin, R. J., D. L. Wagner, D. S. Sweetkind, A. M. Sarna-Wojcicki, J. J. Rytuba, V. E. Langenheim, R. J. Fleck, R. C. Jachens, and A. Deino (2005). Late Neogene transition from transform to subduction margin east of the San Andreas fault in the wine country of the northern San Francisco Bay area, California, Geological Society of America Fieldtrip Guide, Vol. 10, 112 pp.

Olsen, K. B., and R. J. Archuleta (1996). Three-dimensional simulation of earthquakes on the Los Angeles fault system, Bull. Seism. Soc. Am. 86, 575-596.

Phelps, G. A., V. E. Langenheim, and R. C. Jachens (1999). Thickness of Cenozoic deposits of Yucca Flat inferred from gravity data, Nevada Test Site, Nevada, U.S. Geol. Surv. Open-File Rept. 99-310, 33 pp.

Pitarka, A., K. Irikura, T. Iwata, and H. Sekiguchi (1998). Three-dimensional simulation of the near-fault ground motion for the 1995 HyogoKen Nanbu (Kobe), Japan, earthquake, Bull. Seism. Soc. Am. 88, 428440.

Reid, H. (1910). The mechanics of the earthquake, volume II of The California earthquake of April 18, 1906, Report of the State Earthquake Investigation Commission, Carnegie Institution of Washington, Washington, D.C. 
Smith, N. (1992). Gravity interpretation of San Pablo Bay and vicinity, in Field Trip Guide to Late Cenozoic Geology in the North Bay Region T. L. Wright (Editor), Northern California Geological Society, 7180,2 plates.

Song, S. G., G. Beroza, and P. Segall (????). A unified source model for the 1906 San Francisco earthquake, Bull. Seism. Soc. Am. (in press).

Steinbrugge, K. V. (1970). Engineering aspects of the Santa Rosa California, earthquakes, October 1, 1969, in The Santa Rosa, California, earthquakes of October 1, 1969, K. V. Steinbrugge, W. K. Cloud, and N. H. Scott (Editors), U.S. Department of Commerce, Coast and Geodetic Survey, Rockville, Maryland, 1-63.

Trifunac, M. D. (1971). Surface motion of a semi-cylindrical alluvial valley for incident plane SH waves, Bull. Seism. Soc. Am. 61, 1755-1770.

Wald, D. J., and R. W. Graves (1998). The seismic response of the Los Angeles basin, California, Bull. Seism. Soc. Am. 88, 337-356.

Wong, I. G., and J. D. Bott (1995). A new look back at the 1969 Santa Rosa, California, earthquakes, Bull. Seism. Soc. Am. 85, 334-341.

Youd, T. L., and S. N. Hoose (1978). Historic ground failures in Northern California triggered by earthquakes, U.S. Geol. Surv. Profess. Pap. 993, $177 \mathrm{pp}$
U.S. Geological Survey MS 989, 345 Middlefield Rd.

Menlo Park, California 94025

dmcphee@usgs.gov

(D.K.M., V.E.L., R.C.J.)

U.S. Geological Survey

MS 966, P.O. Box 25046

Denver, Colorado 80225

(S.H.)

U.S. Geological Survey

MS 973, 345 Middlefield Rd.

Menlo Park, California 94025

(R.J.M., C.M.)

U.S. Geological Survey

345 Middlefield Rd.

Menlo Park, California 94025

(B.T.A.)

Manuscript received 7 July 2006. 